\title{
Comparative study of efficacy and safety of intravenous ferric carboxymaltose versus iron sucrose in treatment of post-partum anemia
}

\author{
Jayanthy T., Apoorva Asranna, Ragvi Raman*
}

Department of Obstetrics and Gynecology, Kempegowda Institute of Medical Sciences, Bangalore, Karnataka, India

Received: 28 June 2021

Revised: 29 June 2021

Accepted: 30 July 2021

\section{*Correspondence:}

Dr. Ragvi Raman,

E-mail: ragvi16794@gmail.com

Copyright: (c) the author(s), publisher and licensee Medip Academy. This is an open-access article distributed under the terms of the Creative Commons Attribution Non-Commercial License, which permits unrestricted non-commercial use, distribution, and reproduction in any medium, provided the original work is properly cited.

\begin{abstract}
Background: Ferric carboxymaltose has been recently introduced for the treatment of anaemia. The present study was planned to compare the efficacy, tolerability and safety of intravenous ferric carboxymaltose with intravenous iron sucrose in the treatment of iron deficiency anaemia among postpartum women.

Methods: A total of 60 postpartum women with haemoglobin levels between 7-10 g/dl were randomized into two groups: 30 in group A (received iron carboxymaltose) and 30 in group B (Received iron sucrose). Haemoglobin and serum ferritin levels were done on day 0 and after 6 weeks.

Results: The post treatment haemoglobin levels were found to be $10-10.9 \mathrm{~g} / \mathrm{dl}$ in $66.7 \%$ of women in group A and $63.3 \%$ in group B. The mean post treatment haemoglobin levels in group A was $9.97 \pm 0.3 \mathrm{~g} / \mathrm{dl}$ and in group B was 10.9 $\mathrm{g} / \mathrm{dl}(\mathrm{p}<0.001)$. The mean increase in haemoglobin levels post treatment were significantly high in group B $(2.1 \pm 0.5$ gm\%) compared to group A $(1.3 \pm 0.5 \mathrm{gm} \%)$. The mean post treatment S. Ferritin levels in group A was $91.2 \pm 25.8$ and in group B was $126.5 \pm 23.2 \mathrm{gm} \%$. The mean increase in S. Ferritin levels post treatment were significantly high in group B $(96.9 \pm 23.3)$ compared to group A $(62.7 \pm 22.6)(\mathrm{p}<0.001)$.

Conclusions: Intravenous iron carboxymaltose is more effective and better tolerated in the treatment of iron deficiency anaemia among postpartum women compared to intravenous iron sucrose.
\end{abstract}

Keywords: Intravenous iron sucrose, Iron carboxymaltose, Postpartum anaemia, Haemoglobin, Serum ferritin

\section{INTRODUCTION}

Anaemia is a condition in which the number of red blood cells or their oxygen carrying capacity is insufficient to meet physiologic needs. ${ }^{1}$ It is defined by World Health Organization (WHO) as Haemoglobin levels less than 11 $\mathrm{g} / \mathrm{dL} .^{2}$ The functioning of the oxygen binding molecules such as haemoglobin depends largely on the availability of iron. Iron deficiency anaemia is accompanied by depleted iron stores and signs of a compromised supply if iron to the tissues. Iron deficiency anaemia is the most common cause of post-partum anaemia. The physiological effects of pregnancy and blood loss at birth can exacerbate anaemia. $^{3}$

In healthy women after normal delivery, the prevalence of anaemia 1 week postpartum is $14 \%$ in iron supplemented women and $24 \%$ in non-supplemented women. ${ }^{6}$

Treatment of anaemia is important because it is associated with reduced physical endurance, decreased work capacity and fatigue is child bearing women; and is associated with postpartum depression, stress, anxiety, reduced mother child interaction and cognitive impairment. ${ }^{4,7,8}$ 
Although oral iron is easy and cost-effective method of iron replenishment, it has its limitations- gastrointestinal complaints, non-compliance $(32 \%$ after 2 months of administration). ${ }^{5}$ Hence parenteral iron therapy is considered from 2nd trimester onwards and during postpartum period for women with confirmed iron deficiency according to the Obstetric Haematology group UK guidelines (2012) by British Society for Haematology.

Intravenous administration of iron sucrose has been available for several years, has excellent safety record and is administered in small doses of $200 \mathrm{mg}$ over 30 minutes. $^{9-11}$

Intravenous ferric carboxymaltose is recently developed, gives rapid replacement of iron shortage and can by administered in a time of less than 15 minutes; though it is yet to find a place in India for routine use. ${ }^{11-13}$ In this study, we compare and evaluate the safety and efficacy of intravenous ferric carboxymaltose and iron sucrose in the treatment of postpartum iron deficiency anaemia.

\section{METHODS}

The study deign was comparative two group clinical study. The study period was from December 2015 to May 2017. The sample size was 60 (30 in each group).

All postpartum women admitted at Department of Obstetrics and Gynecology, KIMS Hospital, Bangalore, Karnataka, India.

\section{Inclusion criteria}

Postpartum women whose haemoglobin is in the range of $7-10 \mathrm{~g} / \mathrm{dL}$.

\section{Exclusion criteria}

Women not willing to participate, medical disorders like hepatic or renal disorders, tuberculosis, diabetes, acute infections, known hypersensitivity to iron derivatives and parenteral iron treatment, haemolytic anaemia and thalassemia

\section{Methodology}

Demographic data was collected, along with detailed medical history and physical examination.

Haemoglobin, serum ferritin values were noted on day 0 and iron deficit was calculated according to the formula:

$$
\begin{aligned}
\text { Deficit }=(11- & \text { Hb of patient }) \times 2.4 \\
& \times \text { weight }(k g s)+500
\end{aligned}
$$

The women were divided into two groups of 30 each:

Group A ( $\mathrm{n}=30)$ received iron sucrose in a dose of $200 \mathrm{mg}$ intravenously in $200 \mathrm{ml}$ normal saline over a period of
15-20 minutes on alternate days until a total dose was administered; not exceeding the maximum dose of 1000 $\mathrm{mg} /$ week.

Group B (30) received ferric carboxymaltose infusion as follows:

Dilute in $0.9 \%$ sodium chloride

$500 \mathrm{mg}: 100 \mathrm{ml} \mathrm{NS}-6$ minutes duration

$1000 \mathrm{mg}: 250 \mathrm{ml} \mathrm{NS}-15$ minutes duration

Not exceeding the maximum dose of $1000 \mathrm{mg} /$ week.

All doses were given in the ward where equipment for cardiopulmonary resuscitation was available. Patients were observed for side effects or anaphylactic reactions. Any major side effects were documented.

Haemoglobin and serum ferritin estimation was repeated at the end of 6 weeks interval.

\section{Statistical tool}

The categorical data was expressed in terms of frequencies and percentages while continuous data was expressed as mean \pm standard deviation (SD). The two groups were compared using chi-square test for categorical data and independent sample ' $t$ ' test was used to compare the means of different parameters. A ' $p$ ' value of less than or equal to 0.050 was considered as statistically significant.

\section{Ethical approval}

The study was approved by the Institutional Ethics Committee of Kempegowda Institute of Medical Sciences Hospital and Research Centre, Bangalore.

\section{RESULTS}

In this present study, most of the women (46.7\%) were aged between 26 to 30 years in group A while in group B most of the women (40\%) had also age between 26 to 30 years.

Most of the women in the study were booked outside in both group A (73.3\%) and group B (63.3\%).

In our study, most of the women had primi parity in group A $(56.7 \%)$ and multi parity in group B $(53.3 \%)$. However, the parity status of study population was comparable in both groups.

The present study had all women of group A (100\%) and most of the women in group B $(86.7 \%)$ had LSCS. In Group A, 15 patients needed 3 doses and 15 received 5 doses of iron sucrose; and in Group B, all received 1 dose of ferric carboxymaltose (Table 1). 
Table 1: No. of doses given to study participants in Group A (Iron sucrose) and Group B (Ferric Carboxymaltose).

\begin{tabular}{|llll|}
\begin{tabular}{|l} 
No. of doses given to \\
study participants
\end{tabular} & $\begin{array}{l}\text { Group A (Iron } \\
\text { sucrose) }\end{array}$ & $\begin{array}{l}\text { Group B (Ferric } \\
\text { Carboxymaltose) }\end{array}$ & Total N (\%) \\
\hline $\mathbf{N}$ & $0(0.0)$ & $30(100.0)$ & $30(50.0)$ \\
\hline $\mathbf{N}$ & $15(50.0)$ & $0(0.0)$ & $15(25.0)$ \\
\hline $\mathbf{5}$ & $15(50.0)$ & $0(0.0)$ & $15(25.0)$ \\
\hline Total & $30(100.0)$ & $30(100.0)$ & $60(100.0)$ \\
\hline
\end{tabular}

*figures in parenthesis are percentages

Table 2: Pre and post treatment haemoglobin of study participants in Group A (Iron sucrose) and Group B (Ferric Carboxymaltose).

\begin{tabular}{|c|c|c|c|c|c|c|c|}
\hline \multirow[t]{2}{*}{$\begin{array}{l}\text { Haemoglobin } \\
\text { in } \mathrm{mg} / \mathrm{dl}\end{array}$} & \multicolumn{2}{|c|}{ Group A (Iron sucrose) } & \multicolumn{2}{|c|}{$\begin{array}{l}\text { Group B (Ferric } \\
\text { Carboxymaltose) }\end{array}$} & \multicolumn{2}{|c|}{ Total N (\%) } & $\begin{array}{l}\mathbf{P} \\
\text { value }\end{array}$ \\
\hline & $\begin{array}{l}\text { Pre treatment } N \\
(\%)\end{array}$ & $\begin{array}{l}\text { Post } \\
\text { treatment } \\
\text { N (\%) }\end{array}$ & $\begin{array}{l}\text { Pre } \\
\text { treatment } \\
\mathrm{N}(\%)\end{array}$ & $\begin{array}{l}\text { Post } \\
\text { treatment } \\
\text { N (\%) }\end{array}$ & $\begin{array}{l}\text { Pre } \\
\text { treatment } \\
\mathbf{N}(\%)\end{array}$ & $\begin{array}{l}\text { Post } \\
\text { treatment } \\
\text { N }(\%)\end{array}$ & \multirow{5}{*}{$\begin{array}{l}< \\
0.001\end{array}$} \\
\hline$\leq 9.9$ & $4(13.3)$ & $10(33.3)$ & $3(10.0)$ & $0(0.0)$ & 7 (13.3) & $10(16.7)$ & \\
\hline $10.0-10.9$ & $16(53.3)$ & $20(66.7)$ & $16(53.3)$ & $19(63.3)$ & $32(53.3)$ & $39(65.0)$ & \\
\hline$\geq 11.0$ & $10(33.4)$ & $0(0.0)$ & $11(36.7)$ & $11(36.7)$ & $21(35.0)$ & $11(18.3)$ & \\
\hline Total & $30(100.0)$ & $30(100.0)$ & $30(100.0)$ & $30(100.0)$ & $60(100.0)$ & $60(100.0)$ & \\
\hline
\end{tabular}

*figures in parenthesis are percentages

Table 3: Pre and post treatment serum ferritin levels of study participants in Group A (Iron sucrose) and Group B (Ferric Carboxymaltose).

\begin{tabular}{|c|c|c|c|c|c|c|c|}
\hline \multirow[t]{2}{*}{$\begin{array}{l}\text { Serum } \\
\text { ferritin in } \\
\mathrm{mcg} / \mathrm{ml}\end{array}$} & \multicolumn{2}{|c|}{ Group A (Iron sucrose) } & \multicolumn{2}{|c|}{$\begin{array}{l}\text { Group B (Ferric } \\
\text { Carboxymaltose) }\end{array}$} & \multicolumn{2}{|c|}{ Total N (\%) } & $P$ value \\
\hline & $\begin{array}{l}\text { Pre treatment } \\
N(\%)\end{array}$ & $\begin{array}{l}\text { Post } \\
\text { treatment } \\
\text { N }(\%)\end{array}$ & $\begin{array}{l}\text { Pre } \\
\text { treatment } \\
\text { N }(\%)\end{array}$ & $\begin{array}{l}\text { Post } \\
\text { treatment } \\
\text { N (\%) }\end{array}$ & $\begin{array}{l}\text { Pre } \\
\text { treatment } \\
\mathbf{N}(\%)\end{array}$ & $\begin{array}{l}\text { Post } \\
\text { treatment } \\
\text { N }(\%)\end{array}$ & \multirow{5}{*}{$<0.001$} \\
\hline$<75$ & $12(40.0)$ & $10(33.3)$ & $11(36.7)$ & $0(0.0)$ & $23(38.3)$ & $10(16.7)$ & \\
\hline $75-100$ & $17(56.7)$ & $7(23.3)$ & $18(60.0)$ & $3(10.0)$ & $35(58.3)$ & $10(16.7)$ & \\
\hline$>100$ & $1(3.3)$ & $13(43.3)$ & $1(3.3)$ & $27(90.0)$ & $2(3.3)$ & $40(66.7)$ & \\
\hline Total & $30(100.0)$ & $30(100.0)$ & $30(100.0)$ & $30(100.0)$ & $60(100.0)$ & $60(100.0)$ & \\
\hline
\end{tabular}

*figures in parenthesis are percentages

Table 4: Reactions occurred among study participants in Group A (Iron sucrose) and Group B (Ferric Carboxymaltose).

\begin{tabular}{|lllllll|}
$\begin{array}{l}\text { Adverse } \\
\text { reactions }\end{array}$ & Group A (Iron sucrose) & \multicolumn{2}{l}{$\begin{array}{l}\text { Group B (Ferric } \\
\text { Carboxymaltose) }\end{array}$} & Total N (\%) & P value \\
\hline No reactions & $\mathbf{N}$ & $\mathbf{\%}$ & $\mathbf{N}$ & $\mathbf{\%}$ & \\
\hline $\begin{array}{l}\text { Injection site } \\
\text { reaction }\end{array}$ & 1 & 96.7 & 30 & 100.0 & $59(98.3)$ & 0.313 \\
\hline Total & 30 & 3.3 & 0 & 0.0 & $1(1.7)$ & $60(100.0)$ \\
\hline
\end{tabular}

*figures in parenthesis are percentages

The mean pre-treatment haemoglobin levels were $8.8 \pm 0.6$ gm\% in Group A and 8.6 \pm 0.6 gm\% in Group B ( $=0.311)$. Post treatment Haemoglobin levels were found to be 10 10.9 in $66.7 \%$ women in Group A and $63.3 \%$ women in Group B (Table 2).
Majority of women in Group A (56.7\%) and Group B $(60.0 \%)$ had pre-treatment serum ferritin levels between $25-50 \mathrm{mcg} / \mathrm{ml}$. Post treatment serum ferritin levels were found to be $>100 \mathrm{mcg} / \mathrm{ml}$ in $43.3 \%$ women in Group A and $90 \%$ women in Group B (Table 3). 
In this study, only 1 person in Group A (3.3\%) had adverse reaction, which was injection site reaction. There was no adverse reaction seen in Group B (Table 4).

\section{DISCUSSION}

In this study majority of women in Group A (53.3\%) and Group B (53.3\%) had haemoglobin levels between 8.1-9.0 $\mathrm{mg} / \mathrm{dl}(\mathrm{p}=0.909)$. The mean pre-treatment haemoglobin levels were also comparable in Group A and B that is $8.8 \pm 0.6$ gm $\%$ in Group A and 8.6 \pm 0.6 gm\% in Group B $(\mathrm{p}=0.311)$. Majority of women in Group A $(56.7 \%)$ and Group B $(60 \%)$ had serum ferritin levels between 25-50 $\mathrm{mcg} / \mathrm{mL}(\mathrm{p}=0.965)$

Post treatment Haemoglobin levels were found to be 1010.9 in $66.7 \%$ women in Group A and $63.3 \%$ women in Group B. However, this difference was statistically significant.

In a similar study by Jose et al, mean rise in Haemoglobin at 12 weeks was significantly higher in ferric carboxymaltose group as compared with iron sucrose group ( $29 \mathrm{~g} / \mathrm{l}$ versus $22 \mathrm{~g} / \mathrm{l} ; \mathrm{p}<0.01) .{ }^{14} \mathrm{~A}$ similar study by Giannoulis et al in 52 postpartum women with anemia showed an increase in hemoglobin from <8 to $12.6 \mathrm{gm} \%$ post-treatment with iron sucrose. ${ }^{15}$ A study by Breymann et al in postpartum women with anemia showed an increase in hemoglobin from 9.67 to 15.2 post-treatment with ferric carboxymaltose. ${ }^{16}$

Post treatment serum ferritin levels were found to be $>100$ $\mathrm{mcg} / \mathrm{ml}$ in $43.3 \%$ women in Group A and $90 \%$ women in Group B. However, this difference was statistically significant.

A similar study by Giannoulis et al in 52 postpartum women with anemia showed an increase in serum ferritin from $<10$ to $115(\mathrm{ng} / \mathrm{ml})$ post-treatment with iron sucrose. ${ }^{15}$ A study by Breymann et al in postpartum women with anemia showed an increase in serum ferritin from $39.9 \mathrm{mcg} / \mathrm{l}$ to $161.2 \mathrm{mcg} / \mathrm{l}$ post-treatment with ferric carboxymaltose. ${ }^{16}$

In this study, only 1 person in Group A (3.3\%) had adverse reaction, which was injection site reaction. There was no adverse reaction seen in Group B.

In a similar study by Jose et al, no severe adverse effects were noted in either groups. ${ }^{14}$ In other similar studies, patients treated with ferric carboxymaltose had fewer side effects than those receiving iron sucrose, but the difference was not statistically significant.

The purpose of our study is to compare ferric carboxymaltose and iron sucrose in managing patients with postpartum anaemia and to avoid unnecessary blood transfusions. We found that both ferric carboxymaltose and iron sucrose regimens are effective and well tolerated when used in postpartum period but single dose and efficacy of ferric carboxymaltose has better patient compliance.

\section{Limitations}

The sample size was small. Further, multi-centric study with more number subjects maybe justified.

\section{CONCLUSION}

In our comparative study among postpartum women within 6 weeks of delivery and $\mathrm{Hb}$ between $7.1-10.0$ $\mathrm{g} / \mathrm{mL}$, Ferric carboxymaltose required was single dose compared to multiple doses of iron sucrose to achieve higher haemoglobin and serum ferritin values, lesser adverse effects, better patient compliance, and shorter treatment period, less hospital visits and did not require prolonged hospital stay. Though, ferric carboxymaltose is more expensive when compared to iron sucrose, when multiple doses of iron sucrose are required, the overall difference is not very significant. Hence, it was found that ferric carboxymaltose is a better drug when compared to iron sucrose.

\section{Funding: No funding sources}

Conflict of interest: None declared

Ethical approval: The study was approved by the Institutional Ethics Committee

\section{REFERENCES}

1. World Health Organization. The prevalence of anaemia in women: a tabulation of available information. World Health Organization. 1992. Available at: http://apps.who.int/iris/bitstream/ handle/10665/58994/WHO_MCH_MSM_92.2.pdf?s equence $=1$. Accessed on 15 July 2021.

2. World Health Organization, World Health Organization. Reproductive Health, World Health Organization. Department of Reproductive Health. Pregnancy, childbirth, postpartum, and new born care: a guide for essential practice. World Health Organization. 2003. Available at: https://www.afro.who.int/sites/default/files/201706/mps\%20pcpnc.pdf. Accessed on 15 July 2021.

3. Perez EM, Hendricks MK, Beard JL, Murray-Kolb LE, Berg A, Tomlinson $\mathrm{M}$ et al. Mother-infant interactions and infant development are altered by maternal iron deficiency anaemia. The Journal of nutrition. 2005;135(4):850-5.

4. Bodnar LM, Cogswell ME, McDonald T. Have we forgotten the significance of postpartum iron deficiency?. American journal of obstetrics and gynaecology. 2005;193(1):36-44.

5. Brindley PL, Dalenius K, Grummer-Strawn L, Reinold CM, Smith BL. Division of Nutrition, Physical Activity, and Obesity. National Center for Chronic Disease Prevention and Health Promotion. Centers for Disease Control and Prevention. Pregnancy nutrition surveillance. 2007. 
6. Milman N. Postpartum anemia I: definition, prevalence, causes, and consequences. Annals of haematology. 2011;90(11):1247-53.

7. Verdon F, Burnand B, Stubi CF, Bonard C, Graff M, Michaud A et al. Iron supplementation for unexplained fatigue in non-anaemic women: double blind randomised placebo controlled trial. Bmj. 2003;326(7399):1124.

8. Beard JL, Hendricks MK, Perez EM, Murray-Kolb LE, Berg A, Vernon-Feagans L et al. Maternal iron deficiency anemia affects postpartum emotions and cognition. The Journal of nutrition. 2005;135(2):267-72.

9. Bhandal N, Russell R. Intravenous versus oral iron therapy for postpartum anaemia. BJOG: An International Journal of Obstetrics \& Gynaecology. 2006;113(11):1248-52.

10. Bhandal N, Russell R. Intravenous versus oral iron therapy for postpartum anaemia. BJOG: An International Journal of Obstetrics \& Gynaecology. 2006;113(11):1248-52.

11. Perewusnyk G, Huch R, Huch A, Breymann C. Parenteral iron therapy in obstetrics: 8 years experience with iron-sucrose complex. British journal of nutrition. 2002;88(1):3-10.

12. Seid MH, Derman RJ, Baker JB, Banach W, Goldberg C, Rogers R. Ferric carboxymaltose injection in the treatment of postpartum iron deficiency anemia: a randomized controlled clinical trial. American journal of obstetrics and gynaecology. 2008;199(4):435-e1.
13. Breymann C, Gliga F, Bejenariu C, Strizhova N. Comparative efficacy and safety of intravenous ferric carboxymaltose in the treatment of postpartum iron deficiency anemia. International Journal of Gynaecology \& Obstetrics. 2008;101(1):67-73.

14. Jose A, Mahey R, Sharma JB, Bhatla N, Saxena R, Kalaivani M, Kriplani A. Comparison of ferric Carboxymaltose and iron sucrose complex for treatment of iron deficiency anemia in pregnancyrandomised controlled trial. BMC pregnancy and childbirth. 2019;19(1):1-8.

15. Giannoulis C, Daniilidis A, Tantanasis T, Dinas K, Tzafettas J. Intravenous administration of iron sucrose for treating anemia in postpartum women. Hippokratia. 2009;13(1):38-40.

16. Breymann C, Gliga F, Bejenariu C, Strizhova N. Comparative efficacy and safety of intravenous ferric carboxymaltose in the treatment of postpartum iron deficiency anemia. Int $\mathbf{J}$ Gynecol Obstetr. 2008;101(1):67-73.

Cite this article as: Jayanthy T, Asranna A, Raman R. Comparative study of efficacy and safety of intravenous ferric carboxymaltose versus iron sucrose in treatment of post-partum anemia. Int J Reprod Contracept Obstet Gynecol 2021;10:3531-5. 